\title{
Development Policy Process in Nepal: A Critical Analysis Prem Prasad Limbu*
}

\begin{abstract}
Thearticle analyzes the development policy, agendasources, policy formation, iplementation, and evaluation process of Nepal. The description of policy agendas, role of the National Planning Commission (NPC) as development policy agency, trend of planned development approach in Nepal its review target achievements and discussion of identified problems of development plans are also the contents of the article. It further explains the explored problems and ideas to solve them in a complete development policy process Nepal. The article examines the level of social justice analyzing whole development policy process of Nepal along with the interpretation of policy agency through the lance of power sharing based on thematic analysis of data. The article has concluded that the current development policy process is centralized, top-down and elite dominated in a old tendency which is not compatible process to federal structure of Nepal. The reformation of this old tendency through inclusive, bottom- up approach and deconstruction of centralization with insurance of multi-dimensional meaningful participation and ownership development to the concerned stakeholders in all levels is the way of solution. The reformation is necessary in both policy agency institutional structure and policy process of development, such as:, agenda setting, situation analysis, alternative selection, policy adoption, and implementation with due monitoring and evaluation process for the bright future of Nepali peoples.
\end{abstract}

Key words: development policy process, planning, inclusion

${ }^{*}$ Lecturer, CentralDepartment of Political Science, Tribhuvan University

Email:premyekten@gmail.com 


\section{Introduction}

The development policy process is a backbone of the success of politics and a fundamental function of government to overcome varied problems and to manage the demands of people. It is a highly concerned public policy of a state. Government has to build policy relating to burning public affairs either to commence new action for change or to stop some actions, because public policy is "anything a government chooses to do or not to do" (Dye, 1972: 2).

In a state, different types of public policies are formed and operated in society. Among the different types of public policies the policies related to distributive, redistributive and economic growth are the domain of development policy which is known as development planning as well. Since the planning itself is a policy, “...planning...is, in essence, an organized, conscious and continual attempt to select the best available alternatives to achieve specific goals" (Waterston, 1969:26).

The policy in its broader concept includes not only the policy formation but its implementation and evaluation too, in a whole policy cycle. So the development planning as development policy carries the whole policy process of development, since, "...development planning seeks to change that framework in the process of securing an acceleration in the rate of economic and social process" (Ibid: 27).

Thus development policy is closely related to economic activities of a nation, which is converted into plan for implementation to achieve the goal. The plan provides a systematic approach which is useful for stimulating development process. Development plan is the systematic management of resources for the purpose of achieving definite targets or objectives within specific period of time, it is a necessary condition for ensuring rapid development (Shakya, 2008: 10).

Nepal has been continuously employing the planned development policy since 1956. After the commencement of the planned development concept in Nepal fourteen long-term plans have been completed in the leadership of National Planning Commission (NPC). But Nepal is still in ranking of a least developed countries among the 47 countries (UNCTAD, 2017: 5) in global race of development due to less economic growth and less per-capita income of people. Such a weak reality is the background from where the Fifteenth Plan has come into the effect from the fiscal year 2019/20 with the national vision of 'Prosperous Nepal Happy Nepali'.

The national vision of Fifteenth Plan has been targeted to succeed by addressing the people's expectations from comprehensive socio-economic transformation, achievement of high economic growth, insurance of coordinated distribution and redistribution with complete justice to upgrade Nepal in developing country from least developed country 
by 2022, to upgrade the country in the level of middle earning by 2030 and developed country by 2043 as the foundation of transforming Nepal into socialism oriented welfare state with prosperous economy and social justice (NPC, 2019: 2 and 39).

The effective implementation of development policy is the formula to achieve the above mentioned set goals of development. For this, the whole development policy process should be run effectively in its self cycling process where the development agendas are enrolled and forwarded to bring the specific results in a state system. Is it possible from current development policy process?

\section{Methodology}

Bing a policy based qualitative study, it has carried out thematic interpretive analysis with necessary comparison and support of quantitative data. The in-depth interview in individual level with identified concerned development policy process stakeholders and experience based experts has generated information in a step ahead. Identification of potential information sources areas were political leadership with experience of Ministerial governance, development policy and planning expert with experience of NPC governing body, bureaucratic figure with experience of NPC policy and planning process, non-state organization leader with experience of development planning process and publicopinion makers as policy stakeholders. The open-ended factual questions were asked based on their experience, learning on policy program, operation, process, outcomes, monitoring, evaluation and observed lacking parts in process.

NPC's periodic plans, yearly reports, review reports, policy documents, Central Bureau of Statistics (CBS) reports, Ministry of Finance (MoF) survey reports including other related literatures were used to generate secondary level information. Based on these information the individual level's intensive in-depth interviews were conducted to nonrandomly selected interviewees. Interview based data with transcription, summarization, review and verification with supportive and related literatures are employed for thematic interpretation ensuring due ethical standers in the lance of power sharing and social justice.

\section{Development Policy Process}

The debate on problematic issues of the society and exercise of identifying them as the agenda of development begins the process, where, the agenda setting is followed by agendas adoption and formulation of plan in second step. Third step is implementation of planned actions in order to meet targeted goals and objectives. The fourth step is monitoring and evaluation of running programs and projects. 
Figure 1

Development Policy Process in Nepal

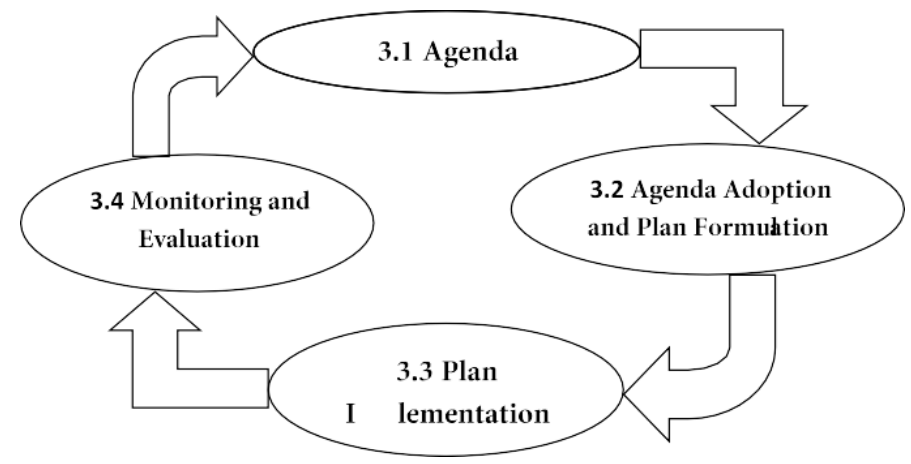

\section{Agenda Setting}

Agenda setting is the first step of development policy process. The problems rooted in the ground of people are main sources; they are in different forms, such as: economic, political, social, cultural, religious, educational, and so on. The policy agendas are aggregated and disseminated by both formal, informal and individual agents. The development agendas are developed to lead the society ahead, therefore, besides the grounded social issues the constitutional, ideological, theoretical and other external components are also agreed as the source of development agendas.

The sources of the agendas are very important to set the development agendas. The problems scattered in different domains are identified, picked up, analyzed, weighted and set as the institutional policy agenda. Thus, "the policy issues are analyzed, weighted and selected the best one as institutional agenda"(Anderson, 2003: 86) to proceed ahead in development sector. The strength of agenda setting depends on the strength of the sources, therefore, the major agenda sources of development policy of Nepal be discussed briefly as below:

\section{Constitutional Provisions}

The political commitments and directive principles of constitution (NPC, 2019: 1) are the foundation for Nepalese development policy. The policies are formed as the provision of constitutional guidance. The theoretical arrangements set in constitution to frame the political system unlock the doors of state development policy. The directive principles of constitution (Article 50) has determined the political objective of state to strengthen federal republican system by assuring of the protection of freedom, equality, proportional participation and social justice through internalizing the principles of inclusion in governance system. The economic objectives of the state is "...to make the national economy self-reliant, independent and developing towards socialism oriented economy 
with equitable distribution of resources and means by ending all forms of economic exploitation and inequality ..." (Constitution, 2015: 20) is an example of policy source for development plan.

\section{Review of Previous Plan}

As the international practice, Nepali development policy has also followed the review of the previous plan as the fundamental source of development policy. The review of the vision, goal, objective and program of previous plan guides to design new plan and policies. The Fifteenth Plan of Nepal has also reviewed the Fourteenth Plan (NPC, 2019: 3) where the major achievements of the determined targets are comparatively analyzed. The fail, success, growth rate, progress status and experiences of difficulties are learnt from review which is also an evaluation of policy agency, leader and implementation effectiveness. It gives the statistical conclusion, situation clarity to identify challenge and innovative preparation of forthcoming agendas.

\section{International Commitments and Donors}

International commitments of the state are strong development agenda sources. The latest example of such source of development policy is Sustainable Development Goals (SDGs). As the commitment of government, current development plan of Nepal has adopted all 17 goals of SDGs as the programs of development as internalized and localized development programs in Federal, Province and Local level (Ibid: 2).

The SDCs has carried on the momentum generated by the Millennium Development Goals (MDGs)to fit into a global development framework beyond 2015. The MDGs, was a historic Millennium Declaration signed by 189 countries in September 2002 at United Nations (UN) with collective commitment to achieve a set of eight measurable goals that range from halving extreme poverty and hunger to promote gender equality and reducing child mortality adopting inclusive and comprehensive approach emphasizing on development as a right by 2015. The date of MDGs finished in 2015 but agendas are continued in post 2015 adding 9 new agendas with the focus of building a sustainable world where environmental sustainability, social inclusion and economic development are equally valued in the name of SDGs. It was processed from the Rio+20 Conference (United Nations Conference on Sustainable Development) in Rio de Janeiro, June 2012 and approved by UN General Assembly in 2015 as a new the global development agenda spanning from 2015-2030(SERIC, 2016:39).

The policy process in Nepal is still governed mainly by government and development partners. "For about seven decades now, international development cooperation has been contributing to the overall development efforts of Nepal" (GNMoF, 2019, P: 1). It shows that the international agencies play a substantial role in shaping the development policies in Nepal. 


\section{Political Party and Non-StateActors}

Philosophical and ideological grounds mentioned in manifestos of political parties are important in policy process. Development vision promised and expressed in election campaign are also policy sources in multiparty democracy. Ruling party's manifesto and commitment keep high value in policy formation just like, socialism oriented programs and eradication of all forms of discrimination (NCP, 2018: 1) are reflections of the Nepal Communist Party manifesto. Like the political parties, non-state actors and economic factors; such as: market, private sector agencies and presser group of concerned stakeholders'(community organization, IPOs, CBOs etc.) also effect.

\section{Ground Problem Analysis and Policy Experts}

Problems of the individuals day to day facing in the society are the fundamental issues. But, to find out such issues and to set as a national development policy is very difficult for those general peoples of the remote areas. The policy experts should be able to excavate those problems and pick up as an national agenda. If the policy experts can identify such issues than only county itself can led the self development process. In this context the white paper of Irish Aid mentions relevant lines, developing countries must lead their own development. The most important actors in development are the individuals, communities and countries. A donor can play the role of supporting and facilitating (Government of Ireland, 2005: 28). It is possible through the bottom-up approach with enough policy research through the concerned policy unites and experts. In this context Neighboring country China's working process may give Nepal a good lesion where the plans in center, province and local level are drafted in corresponding levels by Development and Reforming Commissions respectively (ISC, 2013: 46) and prior information and consent is also taken by the concerned peoples for programs.

\section{Agenda Adoption and Pan Formulation}

The development policy agenda adoption in Nepal takes place from the draft of approach paper which is converted into the development plan through different steps. The major steps are: draft of approach paper, consultation on draft, review of draft and approval of reviewed approach paper by NDC which is forwarded for implementation. Let us observe the agenda adoption and plan formulation steps in brief:

\section{Draft of Approach Paper}

Nepal's Five Year plan's first document is approach paper of development policy and plan. It is initiated by NPC and finalized through the review as per the suggestion received from different level consultations, direction and approval of National Development Council (NDC). The approval of NDC authorizes final form of periodic plan (Ordinance, 2018: 11). 
The approved final plan is systematically organized in frame and submitted to cabinet for its implementation, because the sole responsibility of plan operation rests in executive of Nepal Government. The current Fifteenth Plan has also got the final shape from the same process. It was drafted by NPC and taken into discussion for final suggestion collection and presented to NDC for its finalapproval.

\section{Discussion on Draft Approach Paper}

The draft approach paper of development plan prepared by NPC is discussed in two levels consultation programs: federal level in Kathmandu and province level in capitals of 7 provinces. Federal Lawmakers, political leaders, civil society organization leaders, development partner representatives, former leaders of NPC, activists of different sectors and experts are involved in federallevel consultation. The provincelevel interactions involve province lawmakers, governmental officials, political leaders, stakeholder organization leaders, head and deputy-head of local governments. (NPC, 2019). The discussion is for review and finishing for balanced and practical plan.

\section{Review of Draft}

The draft is reviewed incorporating the suggestions received in the consultations from angle of political leaders, planning experts, government representatives, private sector leaders and other stakeholders. NPC uses to compile the suggestion and edits the sector-wise policies and planning in order to align with the draft of the approach paper. It is concluded through the close consultations at the level of Prime Minister, Ministries, private sectors, community leaders and intellectuals. The meeting of NDC passes the reviewed draft in order to proceed into cabinet.

\section{Final Approval of Reviewed Approach Paper by NDC}

The reviewed approach paper as per the suggestions of different consultation is tabulated to NDC meeting. NDC meeting discusses and approves the paper to proceed for the cabinet's approval. The Fifteenth Plan has also completed the same process and come in to the final form from approval of meeting of NDC in April 2019 and came into effect by the fiscal year 2019/20. The chairman of NPC and NDC Prime Minister KP Sharma Oli, in NDC Meeting, has spoken that the Fifteenth five-year plan would lay the foundation for higher economic growth and national prosperity. We have to work at a war-footing to improve the situation in education, health, governance, human development and infrastructure development in order to ensure a happy and prosperous life to our citizens of Nepal (Nepal24Hours.com, 2019).

\section{Plan Implementation}

The development plan implementation authority lie upon the hand of executive of state and its success also depends on government, “...the secret of successful planning lies more 
in sensible politics and good public administration (Lewis, 2004). The respective Line Ministries have sole responsibility of implementing the policies and plans. Basically the operation of designed policies and plans takes place through the budgeting process. So, it is said that the failure of the government's executive work can cause to fail the development policy. Therefore, the plan operation is related with the budgeting process. So, a short discussion of the Nepali budgeting process in the context of plan implementation is as below:

\section{Budgeting process for plan operation}

Budget is the micro form of long-term development policies and plan designed based on status analysis of country. The policies are converted into the programs thematically for implementation with the resource allocation in a budget. Budget is an annual program which forecasts the annual revenues and expenditures of state. It yearly allocates national resources for the development of the people according to the need and stress of demand.

The budgeting process begins from NPC by approaching to Line Ministry Departments for proposing programs with estimated budget in a structured frame. Line Ministry's planning departs circulates the concerned subordinated agencies and offices for collection and framing of detail needs as future plan in the concerned areas. This process is preceded up to the local bodies and comes back to respected Ministries with proposed programs and budget. Ministries review the received budget programs and forward to NPC (Chaulagain, 2019). NPC also reviews the received programs through different discussion, data based analysis and forwards to Finance Ministry with budget ceiling.

Finance Ministry finalizes the budget with different consultations basically with lawmakers, allocates budget and determine tax and revenue remaining in the ceiling of NPC with direct and indirect consultation with Prime Minister Office. Through the NPC's final approval the budget made ready to present in parliament where the NPC can show the flexibility of around 5-10 percent ups and downs in budget ceiling (Subba, 2019).

Figure 2

Federal Budget Formation Process in Nepal

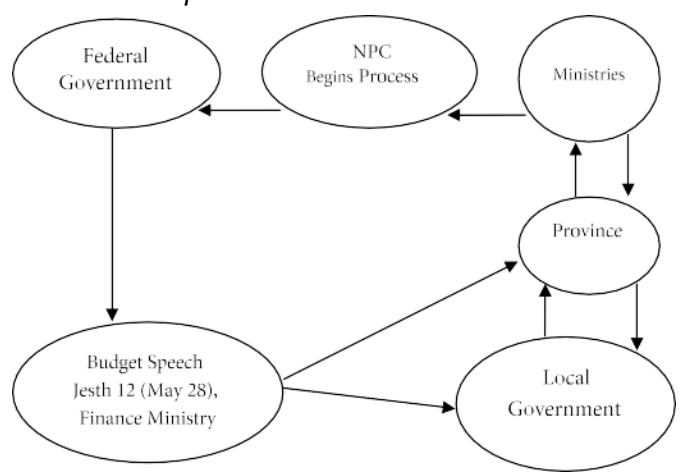


The budget prepared by Finance Ministry is presented in Council of Minister for Approval and finally Finance Minister presents it in parliament. Thus, Finance Ministry is the pivotal agency to shape the budget programs because the budget allocation power lies in it. As the budget resource analysis Finance Ministry finalizes the budget allocation where in Nepali context the heavy influence of Prime Minister and Ministers in powerful political positions lay down. So there is heavy chances to be replaced the public agendas to address vested interest of leaders of different sectors (Kuwar, 2019).

\section{Monitoring and Evaluation}

NPC is an independent monitor and evaluator that can raise significant questions to ongoing programs and projects because the policies, strategies and limitations formed by NPC is mandatory for all respected plan implementer agencies (Ordinance, 2018:18) but there is no any example of such an impressive and exemplary work operated by NPC.

The assessment of priority areas and resource factors for preparation of annual and periodic plans is possible through the monitoring and evaluation of the ongoing development programs. Although this part is not found in a well practice. Until and unless, the meaningful monitoring and evaluation trend is not developed the working may not be efficient. There is a provision that NPC Vice-Chairman should take permission to the Chairman (Prime Minister) for outreach work (Ibid:14), now, there may be question; without interest of Prime Minister how a NPC authority can independently monitor and evaluate the different projects in different areas. The effective monitoring and evaluation of members in their assigned thematic areas must be innovative but it is not found in practice effectively.

\section{Development Planning and Failure to Achieve Target}

Nepal has completed 63 years long planned development practice but many development issues are still unsolved. The practice of shifting major development works into the coming plan in continuous. The review of former plans shows that there are the enhancement of level of people's awareness in comparison to past, entrancement of society into modernization, obtained significant achievements in health, education, drinking water, social security, road, communication technology and urban infrastructure al though most of the infrastructure quality is not ensured yet. There is further need of additional effort in hydro electricity and air transportation (NPC, 2019: 3).

The review has claimed better achievement if health, education social security etc. but the data does not show this as real. Data shows that every plan has become unable to meet the targeted economic growth rate achievement since Ninth to Fourteenth Plan. The continuous achievement is lower than target in economic growth rate. Ninth Plan targeted 6.0 but achieved 3.6, Tenth Plan targeted 7 but achieved only 6.2, Eleventh Plan 
targeted 5.5 but achieved 4.5, Twelfth Plan targeted 5.5 but achieved only 3.5, Thirteenth Plan targeted 6.2 but achieved only 2.9 and Fourteenth Plan targeted 7.2 but achieved only 6.8 (Table 1 and Figure 2)

Figure 1

Long-term Plan wise Yearly Economic Growth Rate Target and Progress

\begin{tabular}{|c|l|l|l|}
\hline S & Periodic Plan & Target & \multicolumn{2}{|c|}{ Growth } \\
\cline { 3 - 4 } N & & \multicolumn{2}{|c|}{ In Percent } \\
\hline 1. & 9 th & 6.0 & 3.6 \\
\hline 2. & 10 th & 7.0 & 6.2 \\
\hline 3. & 11 th & 5.5 & 4.5 \\
\hline 4. & 12 th & 5.5 & 3.5 \\
\hline 5. & 13 th & 6.0 & 2.9 \\
\hline 6. & 14 th & 7.2 & 6.8 \\
\hline 7. & 15 th & 10.5 & - \\
\hline
\end{tabular}

Source: Periodic Plans 15th, 14th, 13th, 12th, 11th, 10th and 9th

The average difference between targeted and achieved yearly economic growth rate shows the failed operation of development plans.

Figure 2

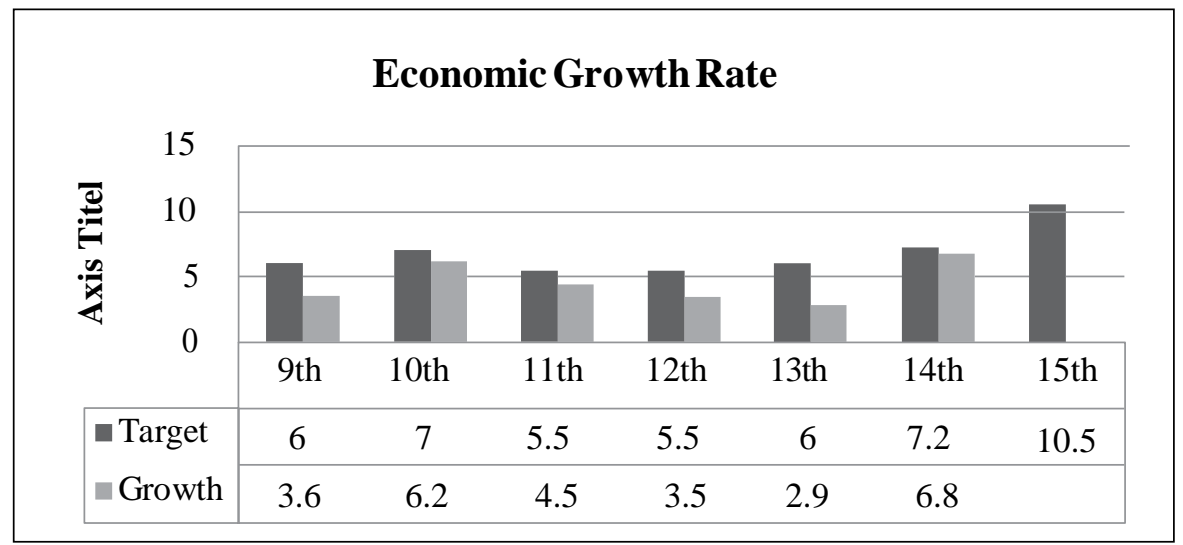

Source: Periodic Plans 15th, 14th, 13th, 12th, 11th, 10th and 9th

Not only the economic growth rate achievement is lower than target but the progress of the indicators of human development is also not satisfactory. it is also seen in the same trend of progress status of economic growth rate. The target is high, achievement is low. If we observe the review of 14th plan; the life expectancy target is 72 but achievement is only 69.7 , reduction target of absolute poverty line population is 11 percent but reduction has been stopped in 18.7 where targeted increase of literacy rate of above 15 years population was 92 but achievement is only 85 (Table 2). 
Table: 2

Human Development Indicators Target and Progress Status Review of Periodic Plans

\begin{tabular}{|l|l|l|l|l|l|l|}
\hline Topic & & 11th & 12th & 13th & 14th & 15th \\
\hline \multirow{2}{*}{ Life Expectancy } & Target & 60 & - & 71.0 & 72 & 80 \\
\cline { 2 - 7 } & Progress & 55.6 & 68.8 & 69.0 & 69.7 & - \\
\hline \multirow{2}{*}{$\begin{array}{l}\text { Literacy Rate (Above } \\
\text { 15 Years) }\end{array}$} & Target & 60 & 60.0 & 95.0 & 92 & 90 \\
\cline { 2 - 7 } & Progress & 55.6 & 87.5 & 88.6 & 85 & - \\
\hline $\begin{array}{l}\text { Population under the } \\
\text { absolute poverty line }\end{array}$ & Target & - & 21.0 & 18 & 11 & 11 \\
\cline { 2 - 7 } & Progress & 21.0 & 23.8 & 21.6 & 18.7 & - \\
\hline
\end{tabular}

Source: Periodic Plans 15th, 14th, 13th, 12th, 11th, 10th, 9th and 8th.

The above data presentation, based on the review of the current previous plans uncovers the condition of critical thinking over the development policy process of Nepal. Why this is happening continuously? What are the causes to fail in achieving the targets in all plans? In the process of seeking the answers of these questions the following policy process problems have been identified that are to be improved for the successful development policy process in Nepal.

\section{Problem in Development Policy Process}

Centralized and top-down approach, elite controlled agenda and plan setting, absence of development policy research, high influence of external factors, weak monitoring and evaluation and exclusion in development policy agency and process are main identified problems that have caused to fail in meeting targeted achievements which are described as below:

\section{Centralized and Top-down Approach}

The Fifteenth Plan formation process represents centralized and top-down approach of development plan. It begins from the thematic draft initiated by governing body members of NPC and dropped to stakeholders for their feedback through consultation programs. But, consultation programs for feedback werelimited in Kathmandu and capital cities of provinces (The Himalayan Times, 2019). Some previous plans' formation process is also in the same process. The Sixth Plan in Panchayat period was drawn up with cooperative and suggestion of the different Ministries, Departments and Corporation of His Majesty's Government and other Governmental, Semi-Governmental, and non-Governmental agencies and some intellectuals (NPC, 1980). TenthPlan has mentioned the discussion programs wereorganized at regional level involving representatives of the village development committees, district development committee and municipalities to determine the framework of the plan. At the national level, consultations were held with parliamentary committees, parliamentarians, academia and sectoral experts (NPC, 2002: 2). 
Twelfth Plan has also conducted two level of consultation program in national and regional level (NPC: 2010). Thus if we observe the level of consultations, all are not more than two level, central and regional. These all representation positions for suggestion collection do not touch the people of ground level. The participants of the consultation are also highly influenced by the pre-structured idea of included in draft by the Kathmandu based elite controlled thought. Such a weak representative position of grass root Nepali people in development policy formation cannot represent the real aspiration and need of the people.

\section{Over Domination of Political Party and Elite}

Determining the distinct qualification (Ordinance, 2018) for NPC members, law itself has maintained strong hegemony of limited elite groups in Nepali development policy process. As legal provision elites are enjoying as their highest economic, social and political power positions. It is promoting the perpetual inequality which is not in favor of good policy and planning. It is found in both policy making agency and policy making process. We are in inclusive democratic and federal state, with the belief of equality, but the policy institutional NPC is still in centralized system without implementation of inclusive composition. In short, it is exclusionary. After the restoration of democracy in 1990 total six long term and interim plans formed where 39 policy leaders contributed in capacity of NPC Vice-Chairman and members among them 62 percent constituted by Hill Brahama Kshetri, 23 percent by indigenous, 13 percent by Madhesi and women have 5 percent representation (Table 3) where Dalit representation is zero.

Table: 3

Representation in NPC Governing Body 2002-2024(10th-15th)

\begin{tabular}{|l|l|l|l|l|}
\hline Plan & $\begin{array}{l}\text { Hill Braham } \\
\text { Kshatri }\end{array}$ & Madhesi & Indigenous & Women \\
\hline 15 th & 5 & 1 & 1 & 1 \\
\hline 14 th & 3 & - & 4 & - \\
\hline 13 th & 7 & 1 & - & 1 \\
\hline 12 th & 3 & 1 & - & - \\
\hline 11 th & 4 & - & 4 & - \\
\hline 10 th & 2 & - & - & - \\
\hline Total & $\mathbf{2 5}$ & $\mathbf{5}$ & $\mathbf{9}$ & $\mathbf{2}$ \\
\hline Percentage & $\mathbf{6 4} \%$ & $\mathbf{1 3 \%}$ & $\mathbf{2 3 \%}$ & $\mathbf{5 \%}$ \\
\hline
\end{tabular}

Source: 10 th, 11th, 12th, 13th, 14th and 15 Plan.

Dalit, a socio-culturally suppressed group of society has zero percent representation in state development policy designing agency in a democratic country Nepal. It is not good. This data shows the whole development policy process is being controlled by limited groups elite groups in the name of expertise and meritocracy. It is legally designed and practiced in Nepal. The concept of institutional formation of NPC found highly entangled by Weberian meritocracy (Weber, 1966) rather than expertise. 
As NPC Composition and Operation Ordinance, Nepal government appointments the NPC Vice-Chairman and members based on the following some defined criteria:

1. Ph. D. in economic and social development, environment, science, engineering, management and good governance from Universities recognized by Nepal Government, or,

2. University Professor, or,

3. Specialization from minimum 10 years working in policy, development, plan, research, management and academic sector holding Master Degree from Universities recognized by Nepal Government,

4. Age 40 years completed Nepali People, (Ordinance, 2018: 3).

Above criteria is blindly supportive to meritocracy universalized by bureaucratic model of Max Weber (Sharma and Sadana, 1999: 346) it is an oldest concept but still highly being applied in Nepal. Political leadership is an important factor in setting agendas. Political leaders, whether motivated by thoughts of political advantage, the public interest, or their political reputations, may seize upon problems, publicize them and propose solutions, but sometimes such influences may uncontrolled due to the interest of electoral benefits, historical achievement and consideration of good policy (Anderson, 2003: 90). Nepali policy process is facing such problem in high range. Legally, NPC Vice-Chairman and members are appointed based on merit and expertise, however, practically ruling party appoints its committed follower. Current Vice-Chairman's appointed is also in same process (The Kathmandu Post: 2018). It shows that there is weak chance of independent policy thinkers, experts and contributors without ruling party's connection.

\section{Absence of Development Policy Research}

Policy study is most important part for development planning. The development policy agency, National Development and Reform Commission (NDRC) of People's Republic of China, 2nd largest economic power of World has a strong and separate department of policy studies to draft important documents, organize studies on concerned key issues for national economy, social development and international economy to give a new work of information guideline (ICS, 2013: 34). But, NPC has not such any specific and active unit to work up to the concerned area. So in absence of such development policy study units it is difficult to identify the state's internal problem based on national interest, this is a serious problem is Nepal.

For development policy and planning the NPC requires a sustainable and timely flow of reliable data, however, Nepal's National Statistical System (NSS) is also has several 
constraints, which is hampering in policy designing. The NSS focus the data generation just as the need of government and administration without including huge part of data realm related to development. Based on such NSS data system NPC is working with a huge data lacking in policy process. For instance, NPC mapped 425 indicators for SDGs requirement in 2015 but the data were available for only 249 indicators, data partially available were of 75 indicators and data were not found for 100 indicators. Thus use of data generally generated without adequate disaggregated to age, sex, caste, ethnicity, reason and disability from the government system do not necessarily addressing the demands of the civil society, private sectors, academia, consumers, indigenous groups and so on (BU, 2018: 3, 16and 155).

\section{External Influence}

Nepal has long history of external support. "For about seven decades now, international development cooperation has been contributing to the overall development efforts of Nepal" (GNMoF, 2019: 1). Many development plans especially the mega plans which need large amount of fond could be conceptualized but the cost for construction is to be approached to the external sources. It is bigger problem for state because the donor may not be ready if they do see any benefit in either form. The sustainable development goals are also influenced by the international SDGs Fund. The various external influences like I/NGOs, International Multi-national corporations and internal elites dominate over the public interest are strong in Nepalese context. Practice of imitating policy substances from the other countries without realizing the different domestic needs and context and influenced by international agencies which may not reflect the welfare of the country. So, the policy process should be converted into the prioritization of the domestic agencies and issues of Nepal.

\section{5 Exclusion in Development Policy Formation}

One major agenda source of policy and planning is voice of the concerned stakeholders and needy groups. For this exclusion should be stopped and inclusion should be practiced, because,

"inclusive processes areimportant to giveall segments of society accessto government decision making in order to better reflect their needs and aspirations, both in policy making and in service delivery. ... inclusive processes increase awareness across the policy cycle and help to orient institutions in support of inclusive outcomes" (Gent, 2017: 7).

But in Nepali development process insurance of inclusion of needy group and concerned stakeholders are not appreciated. Lawmakers, ministers, former policy leaders, representatives from various organizations, major political party representatives, district 
coordinators and head and deputy heads of local bodies (NPC, 2019) are involved in National and province level consultation just to comment upon pre-formed draft of NPC. They are not invited to give a new policy agenda. This two levels (in Kathmandu and Province Capitals) policy consultation process could not been able to include larger groups of policy stakeholder for development. So such process cannot assure to building the policy process inclusive.

Development policies and plans are concerned to all people equally that only increases inclusive growth, since, "inclusive growth is crucial not only for a fairer society but also for a stronger economy" (OECD, 2015:26). The development policy and plan should touch all areas, genders, ethnics, casts, communities, groups proportionally. To maintain the justice the benefit sharing and distribution with equality and proportional inclusive participation for decision making is important in a diverse society because "... economic growth is not sufficient on its own in improving the welfare of a population" (Gent, 2017: 7).

\section{Conclusion}

Ultimately, the result of politics is measured empirically in the realm of development where development is not only a pure economic phenomenon, but also a multi-dimensional process of reorganizing and reorienting of entire economic and social system which seeks the improvement of quality of all human lives and in a protected ecology. The existing Kathmandu centered policy institution and one way development policy process cannot be relevant in federal system of Nepal. Since, "in a federation responsibilities are shared between the centre and the states. A single Planning Agency for the centre and the states is therefore inappropriate" (Lewis, 2004: 247). The continuity of an old tendency of unlimited intervention in all sector of development policy will not be a compatible model in newly established federal state system. Its reformation based on federalism with strategic importance for drastic change which may play the role of game change in competitive state development and growth of human development index in national level in spite of being entangled in the periphery of small business guided by the petty political interests for the sake of ritual consistency.

There is a need for working from two way approaches; national to local and local to the national levels basically local to national. This is possible only through massive inclusion, creative dialogue and interaction among the all concerned units and stakeholders. For this, planning commission should nurture policy dialogues among leaders of all sectors and levels. So the policy process should be seen as a collective process for all Nepali people equally. Top-down approach dependent to elite controlled knowledge system and party controlled so-called merit based policy agency composition with less prioritized process of ensuring mass participation in whole development policy process has vibrantly sustained the centralized and incomplete policy and planning process. Therefore, the deconstruction 
of elite controlled, centralized and top-down policy process into the bottom-up approach to ensure multi-dimensional participation is a way of solution. It will help to generate the ownership of stakeholder in related policy that will be useful to accelerate the activeness, ensures the sustainability and productive.

Insufficient research in policy realm has ever produced the weak alternative selection for need based and game changer (Sharma, 2019: 5) policy and planning formation as the demand of state geopolitical and socio-cultural asymmetrical dynamics. So, sixty three years long journey of planned development model has contributed only in a slow motion with failures in many targets of change. So, the correction of the above mentioned problems in institutional structure, agenda setting, situation analysis, alternative selection process as decision and implementation of plan is inevitable. There is not complete abolition of class, caste, gender, regional inequality in Nepal. Discrimination and exclusion are alive both in economic and social realm. The efficient development policy process can eradicate such all types of problem for the prosperous and well being of Nepali people. It is possible if follow and sincerely implement SDGs declaration no 16, "promote peaceful and inclusive societies for sustainable development, provide access to justice for all, and build effective, accountable and inclusive institutions at all levels (SESRIC, 2016: 39) where the effective monitoring and evaluation mechanisms and practice should be developed for meaningful change and development in Nepal.

\section{Reference}

Anderson, J. E. (2003). Public policymaking: An introduction (5th ed). Boston: Houghton Mifflin.

Bikash Udhyami. (BU). (2018). A study into development data in Nepal. Bikash Udhyami.

Chaulagain, Tirtha. (2019). Personal interview. [01-42111133].

Dye, Thomas R. (1972). Understanding public policy. Englewood Cliffs: Prentice-Hall.

Gent, Shanina van. (2017). Beyond buzzwords: what is “inclusive development". Leiden: INCLUDE.

Government of Nepal Ministry of Finance (GNMoF). (2019). International development cooperation policy, 2019. Kathmandu: Government of Nepal Ministry of Finance.

ICS. (2013). The Planning Process of China. Delhi: Institute of Chinese Studies.

Kuwar, P. B. (2019). Personal Interview. [9841438538].

Lewis, W. A. (2004). Development planning: the essentials of economic policy. London: Routledge. 
Ministry of Finance. (2018). Economic survey 2017/18. Kathmandu: Nepal Government, 'Ministry of Finance.

Nepal24Hours.com. (2019). National development council finalizes Nepal's first federal periodic plan. Retrieved in June 19, 2019 from https://www.nepal24hours.com/ national-development-council-finalizes-nepals-first-federal-periodic-plan/.

Nepal Communist Party (NCP). (2018). Interim manifesto of Nepal communist party 2018. Kathmandu: Nepal Communist Party, Central Office.

Nepal Government, (2018). National planning commission formation and operation ordinance. in Nepal Rajpatra, Kathmandu: Nepal Government.

Nepal Law Society, (2015). Constitution of Nepal. Kathmandu: Nepal Law Society.

NPC. (2019). Approach paper of fifteenth plan (Fiscal Year 2067-67 to 2080-81 B.S.). Kathmandu: National Planning Commission.

. (2017). Annual report 2074-75 B.S. Kathmandu: Nepal Government, National Planning Commission.

. (1980). Sixth plan. Kathmandu: National Planning Commission.

. (2018). Vision concept paper 2100. Kathmandu: National Planning Commis sion.

. (2017). Fourteenth plan (2073/74-2075/76 B.S.). Kathmandu: National Planning Commission.

. (2071). Thirteenth plan (2070/71-2072/73). Kathmandu: National Planning Commission.

. (2068). Three year plan (2067/68-2069/70). Kathmandu: National Planning Commission.

. (2074). Nepal sustainable development goals, current status and future roadm ap. Kathnmandu, National Planning Commission.

. (2010). Twelfth plan (Fiscal Year 2067/68-2069/70). Kathamandu: National Planning Commission.

. (2002). Tenth plan (Fiscal Year 2002-2007). Kathamandu: National Planning Commission.

OECD. (2015). "Inclusive government for a more inclusive society". Government at a Glance 2015, Paris: OECD Publishing.

SESRIC. (2016). Moving from MDGs to SDGs prospects and challenges for OIC mem ber countries. Ankara: SESRIC. 
Shakya, Rabindra K. (2008). Formulation of development plans - planning techniques. Administration and Management Review, 19(2), 8-16. Retrieved November 10, 2019 from https://www.nepjol.info/index.php/AMR/article/view/894.

Sharma, M.P. and B. L. Sadana. (1999). Public administration in theory and practice. Allahabad: Kitab Mahal.

Sharma, Pitambar. (2019, May 22). National planning commission in federal structure. Naya Patrika, p. 5.

Subba, Chaitnya. (2019). Personal interview. [9851089413].

The Himalayan Times. (2019). NPC Collecting suggestions on periodic plan. Retrieved July 9, 2019 from https://thehimalayantimes.com/nepal/national-planning-com mission-collecting-suggestions-on-periodic-plan/.

The Kathmandu Post. (2018). Kandel appointed NPC Vice-Charman. Retrieved August 1, 2019 fromhttps://kathmandupost.ekantipur.com/news/2018-04-24/ cabinet-meeting-kandel-appointed-npc-vice-chairman.html

UNCTAD, (2017). United nations conference on trade and development the least devel oped countries report 2017. New York: UN Publication.

Waterston, A. (1969). Development planning: Lessons of experience. Washington, D.C.: The World Bank.

Weber, M. (1966). The theory of social and economic organization. New York: Free Press. 